Bulletin d'études orientales

\title{
Abbasid Mazālim between Theory and Practice
}

\section{Maaike van Berkel}

\section{(2) OpenEdition \\ Journals}

Electronic version

URL: http://journals.openedition.org/beo/3224

DOI: $10.4000 /$ beo.3224

ISSN: 2077-4079

Publisher

Presses de l'Institut français du Proche-Orient

\section{Printed version}

Date of publication: 1 April 2015

Number of pages: $229-242$

ISBN: 978-2-35159-707-1

ISSN: 0253-1623

Electronic reference

Maaike van Berkel, «Abbasid Mazālim between Theory and Practice », Bulletin d'études orientales [Online], LXIII | 2015, Online since 01 April 2017, connection on 19 April 2019. URL : http:// journals.openedition.org/beo/3224; DOI : 10.4000/beo.3224 


\section{Abbasid Mazālim between Theory and Practice}

Maaike VAN BERKEL

Abstract: There is no doubt that many subjects of the Abbasid empire suffered from abuse by officials on a regular basis. However, they could file petitions, complaining about the misbehaviour of officials and the injustices caused by their actions through an institution which is generally, but inconsistently, referred to as mazālim. This article will argue that in the Abbasid period, the functioning of mazālim was much less well defined and probably also less well organized than later theorists such as al-Māwardī claimed it to be. Most importantly, it lacked a clear definition of its jurisdiction. In practice it consisted of a process of hearing and responding by representatives of the state to complaints and requests filed by subjects of the state. As such, it not only served the aggrieved subject, but also provided the authorities with an instrument through which they could control and regulate their own officials.

Keywords: Abbasids, maz̄ālim, petitions, administration, bureaucrats, good governance.

Résumé : Il fait peu de doute que nombre de sujets de l'empire abbasside se trouvaient régulièrement victimes d'abus de la part des autorités. Ils pouvaient cependant soumettre des pétitions, dans lesquelles ils se plaignaient du comportement répréhensible d'agents du pouvoir et de l'injustice résultant de leurs actions, par le biais d'une institution qui est de manière générale (mais non systématique) appelée mazālim. Cet article soutient qu’à l'époque abbasside, le fonctionnement des mazālim était beaucoup moins défini, et probablement moins organisé aussi, que ce que des théoriciens plus tardifs comme al-Māwardī prétendent. Surtout, sa juridiction n'était pas définie de manière claire. En pratique, l'institution consistait en un processus d'audition, par des représentants de l'État, de plaintes et de requêtes déposées par des sujets, et de réponse à celles-ci. Ainsi, elle ne servait pas seulement les personnes lésées dans leurs droits, mais fournissait aussi aux autorités un instrument de contrôle et de régulation de leurs propres agents.

Mots-clés : Abbassides, mazālim, pétitions, administration, bureaucratie, bon gouvernement. 


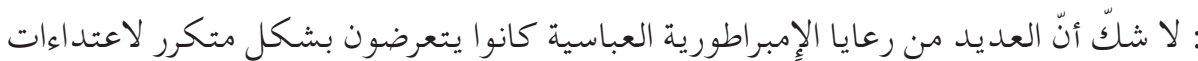

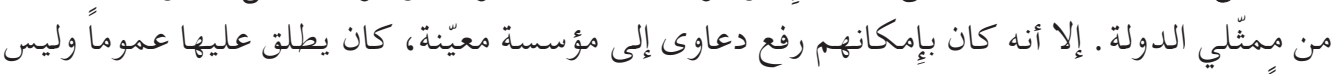

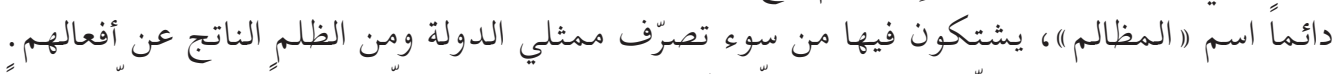

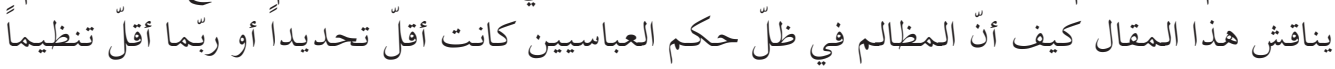

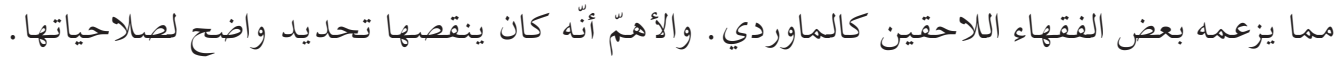

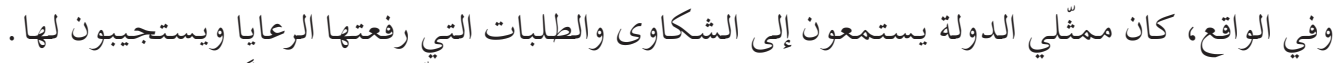

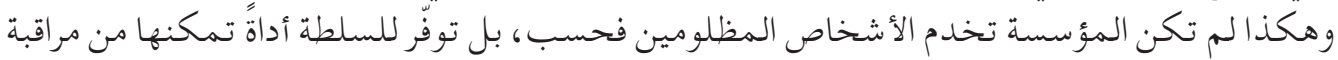

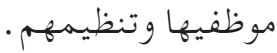

الكلمات المحوريّة : العصر العباسيّ، المظالم، الشكاوى والطلبات، الإِدارة، الكتّاب، الحكومة الصالحة . 


\begin{abstract}
"It is absolutely necessary that on two days in the week the king should sit for the redress of wrongs, to extract recompense from the oppressor, to give justice and to listen to the words of his subjects with his own ears, without any intermediary. It is fitting that some written petitions should also be submitted if they are relatively important, and he should give a ruling on each one. For when word spreads throughout the kingdom that, on two days in the week, The Master of the World summons complainants and petitioners before him and listens to their words, all oppressors will be afraid and curb their activities, and no one will dare to practise injustice or extortion for fear of punishment."
\end{abstract}

This quotation from the fifth/eleventh-century Persian mirror for princes by the famous Salğūq vizier Niz̄ām al-Mulk (d. 485/1092) expresses the ideal of an accessible ruler dealing personally with the redress of wrongs. Such a ruler, who sits down and listens to the grievances of his subjects, is also a recurring topic in most of the earlier (Abbasid) advice literature and chronicles. The institution through which the ruler dealt with his subjects' complaints is generally, but inconsistently, referred to in the sources as mazālim.

While the instructions for a just ruler are quite clear, we are much less well informed about the actual practice of mazālim. There are few studies on the functioning of mazālim. Extensive work has been done by Émile Tyan in his Histoire de l'organisation judiciaire en pays d'Islam. ${ }^{2}$ Although it is an indispensable guide to the theoretical rules and regulations regarding mazālim, we can today take a few steps further, especially given that Tyan's book lacks a thorough historical survey of the institution. A similar focus on the theory of mazālim can be found in later surveys on the history of Islamic law, and these later studies generally contain much less detail on the institution. ${ }^{3}$ Pioneering work on mazālim practices has been done by Samuel Stern and Jørgen Nielsen for the Fātimid, Ayyūbid, and Mamlūk periods. ${ }^{4}$ Using documents - the actual petitions or their responses - they analyzed the relation between the theoretical expositions and the every-day functioning of mazālim in Egypt. Their work has been carried on by, among others, Marina Rustow, who works on petitions from the Cairo Geniza collection. ${ }^{5}$ The Umayyad and Abbasid mazālim practices have recently been the object of increasing interest. For the Abbasid era, Mathieu Tillier has produced valuable research on the mazālim as the expression of political justice and as a tool of legitimacy for the Abbasid dynasty in general and their use of state violence in particular. For the Umayyad period, Lucian Reinfandt has analyzed some early petitions

1. Nizām al-Mulk, The Book of Government or Rules for Kings. The Siyar al-muluk or Siyasat-nama of Nizam al-Mulk, p. 13-14. The translation is by DARKE with some modifications in wording.

2. TYAN 1960 , p. 433-525.

3. See, for example, VIKøR 2005 and ZUBAIDA 2003.

4. NIELSEN 1985; STERN 1962; STERN 1964; STERN 1966. See also KHAN 1990a; KHAN 1990b; RICHARDS 1973; RICHARDS 1977; RICHARDS 1992.

5. See, for example, RUSTOW 2010. 
on papyrus, emphasizing the role of the middle-level administrators, the pagarchs, and his subalterns, in addressing complaints. ${ }^{6}$

In this paper I will bring together scattered information on mazālim for the late third/ninth and early fourth/tenth centuries, a period particularly rich in sources on administrative practices. I will argue on the basis of this material that, in its formative (Abbasid) period, the functioning of mazālim was much less well-defined and probably also less well-organized than later theorists such as al-Māwardī (d. 450/1058) claim it to be. However, I hope to demonstrate that petition and response procedures nevertheless did exist in this period, in practice as well as in theory, and that we learn most about these practices by combining the information from the various types of sources that have come down to us, both narrative and documentary.

\section{Sources and definition}

The lack of attention so far to mazālim practices in the first four centuries of Islam is undoubtedly due to the relative poverty of the source material. There is no extensive theoretical consideration of mazālim before the fifth/eleventh-century work by al-Māwardī. ${ }^{7}$ Earlier authors of judicial and political treatises do not seem interested in mazālim. Al-Buhārī has a chapter "Mazālim" in his Șahihh, but this contains nothing on procedures and does not present a theoretical approach to mazālim as an institution, giving instead examples of types of wrong. ${ }^{8}$ The theoretical exposition by al-Māwardī is valuable for research on mazālim in the Abbasid period, but it has limitations. His treatise is from the middle of the fifth/eleventh century, that is, a century after the waning of the political power of the Abbasid caliphs, and, more importantly, it is normative in the sense that al-Māwardī is presenting the way in which mazālim should function rather than how it actually did function.

The mazālim practice of the period before al-Māwardī must be inferred from scattered fragments of information in chronicles, in works of adab, such as histories of viziers and administrative manuals ( $a d a b$ al-kātib), and in documents, that is, the actual petitions and their answers. These sources, too, have serious limitations.

The first limitation is that both the narrative and documentary sources lack full reports on specific cases and procedures. The references in narrative sources often contain only a few lines and are restricted to a description of parts of the procedures, such as the final verdict. Documents are similarly incomplete, either because parts of the text are lost

6. TILLIER 2009. On the Abbāsid mazālim see also VAN BERKEL 2011. For the Umayyad period see the article of REINFANDT in the present volume.

7. Because it was al-Māwardī's intention to restore the authority of the caliph, it is not surprising that he paid attention to mazālim and especially to the caliph's role in it.

8. Al-Buhārī, Șahịḥ, II, p. 97-109 (kitāb 46). 
or illegible or because we have only one letter in what seems to have been an extensive correspondence.

Secondly, the sources are distributed unevenly geographically. While most of the narrative sources deal with mazālim processes in Baghdad, all documentary sources for this period are from Egypt. The material from the documentary sources concerns complaints brought before local and provincial authorities, whereas most of the non-documentary sources deal with cases brought before the caliph or, more often, his representative, the vizier.

Thirdly, there is the problem of terminology. In the Abbasid period the redressing of wrongs by the ruler or one of his representatives is very inconsistently referred to by the term mazālim. Many other terms are used both for petitioning or complaining and for the action taken on a petition or complaint. The documentary sources do not refer to mazāalim at all in the first three centuries of Islam and only sporadically thereafter. ${ }^{9}$ The documents often do not even use the term zulm (injustice, oppression, tyranny). In some narrative sources the term mazālim itself is not used.

The question that arises from the inconsistent use of the term mazālim is whether petitioners and the officials dealing with petitions always considered their dealings part of something called mazālim. Were these petitions even seen as part of one and the same distinguishable institution or mode of justice? The variation in terminology suggests that we are dealing with various types of administrative processes that were not yet - or at least not by everyone - seen as part of one mode of justice.

Even the detailed theoretical exposition by al-Māwardī leaves much doubt as to how to define the jurisdiction of mažālim. Indeed, al-Māwardī mentions ten classes of cases that could be dealt with by mazālim - some deal with official abuse and others with the function of mazālim as a court of appeal. Yet, while these cases seem to refer to a more or less strict demarcation of jurisdiction, the descriptions of other cases are less precise. For example, the tenth category involves interceding between opponents and deciding on disputes in general. ${ }^{10}$ Mazālim seems to function here as an ordinary court, and its jurisdiction cannot be strictly defined. ${ }^{11}$

The adab and documentary sources corroborate this view. The petitions and complaints I have so far come across in documents and narrative sources cover a wide variety of topics: many, perhaps the majority, deal with abuse by state officials, but there are also requests for financial support, petitions on various kinds of disputes (e.g., a dispute between shopkeepers, and a conflict between farmers and traders on the size of a bridge), and complaints related to religious conflicts on, for example, the presence of a Hanbali

\footnotetext{
9. So far, only two references to mazālim are known from papyri; both cases concern marriage contracts in which mazālim refers only to the competency of a judge rather than to a process of petitioning: P.Cair.Arab. I no. 45 and P.Khalili I no. 32. I would like to thank Lucian Reinfandt, Marina Rustow, and Petra Sijpesteijn for helping me locate these references.

10. Al-Māwardī, al-Ahkām al-sulțāniyya, p. 101-104. See also AMEDROZ 1911, p. 637-641, and NIELSEN 1985, p. 21-23.

11. See also TILLIER 2009, p. 42.
} 
mosque in a Baghdad neighborhood and on alleged religious discrimination against monks in Egypt. ${ }^{12}$ This article will focus on the cases dealing with misuse of power by officials, the prototypical type of mazālim case.

\section{Three fragments}

The shortcomings in the material can best be overcome by bringing together as many bits and pieces as possible from as many diverse sources as possible. It is from the combination of narrative and documentary sources that we might expect to gain the most. The narrative sources are richer in their description of procedures, but, at the same time, they seem to represent the functioning of the mazālim in a more normative than descriptive manner. They often provide examples of good governance, highlighting an accessible ruler who is redressing wrong. The description in the narrative sources should therefore be counterbalanced by the documents that show the day-to-day functioning of the petition-and-response processes.

As an example, I will consider side by side three different types of sources: a description from an administrative manual, Qudāma b. Ǧa'far's Kitāb al-harāăg, of how maz̄ālim procedures should function; a narration from Hilāl al-Șābi"s Tuhfat al-umarā' fì ta'rih al-wuzarā' on the development of a specific complaint; and a fragment from a papyrus petition to the governor of Egypt.

Qudāma b. Ğa'far

Qudāma b. Ğafar (d.337/948) was a scribe in various dīwān-s of the Baghdad administration during the reign of caliph al-Muqtadir (r. 295-320/908-932). Many administrative treatises were written in this period, but only a few of them refer to mazālim. ${ }^{13}$ In his administrative manual Kitāb al-harāă (The Book of Land Tax), Qudāma b. Ğa'far discusses mazālim as one of the fields of administrative expertise: ${ }^{14}$

He [the șähib dīwān al-mazālim] is to collect all petitions and submit them with the caliph on each Friday... And when the session over which the caliph or his deputy presided ends, he is to gather all the petitions divided into groups, enter the groups in the diwān, and note down the names of those who submitted the petitions and record the responses on the petitions. The petitions should then be returned to them [the plaintiffs], so that no trick or forgery can enter into the notes [on the petition]. For if the plaintiff returns one, two, three times or more,

12. For a comparison with the subject matter of Mamluk mazālim cases, see NIELSEN 1985, p. 43-47. Nielsen similarly concludes that « about one half of the administrative cases deal with complaints of official malpractice. »

13. For another reference to mazālim in a contemporary administrative manual, see Ibn Wahb (d. 4th/10th c.), al-Burhān fì wuğūh al-bayān, p. 369-370. Many of the other administrative manuals - such as al-Șūlī (d. 335/947), Adab al-kuttāb, Ibn Qutayba (d. 276/889), Adab al-kātib, al-Naḥhās (d. 318/930), Șināat al-kuttāb, Ibn Durustawayh (d. 346/957), Adab al-kuttāb, and Abd Allāh al-Bag̉dādī (d. after 255/869), Kitāb al-kuttāb wa-șifat al-dawāt wa-l-qalam wa-tașrîfuhā- do not discuss mazālim.

14. The work of Qudāma b. Ğa far is remarkable for its arrangement according to impersonal administrative offices (dīwān-s) rather than according to the individuals working in the various administrative units. 
his entire case is recorded in one place, so that, if a request is made to produce the case from the diwān al-mazālim, his entire dossier will be found in proper order and in its entirety in one place, and the chief of the diwān can produce it without trouble. ${ }^{15}$

\section{Hilāl al-Ṣābi'}

Hilāl al-Ṣābi' (d. 448/1055) was a scribe of the Būyid administration who wrote a history of former viziers entitled Tuhfat al-umarä' fi ta'rih al-wuzarā'. The part of this book that survives contains the descriptions of the viziers of caliph al-Muqtadir. Hilāl al-Șābi' wrote a century after the time of al-Muqtadir but based his information on spokesmen and documents from that time. His work contains many reports on mazālim cases. The following quotation is from one of these. It describes the way in which Ibn al-Furāt (d. 312/924), the famous vizier to caliph al-Muqtadir in the early fourth/tenth century, ${ }^{16}$ dealt with a petition by an estate holder from the Sawād, Iraq, who felt his land had been overtaxed.

A man from the Sawād complained to Ibn al-Furāt about a certain revenue officer. He stated that his estate was an administrative grant ( qatiti $a^{17}$ ) with long-standing privileges of reduced taxes. He had, however, received an [excessive] assessment of it, based on the method of istā $n^{18} . .$. He wrote a petition (ruq $\left.{ }^{\prime} a\right)$, and [the vizier Ibn al-Furāt] ordered an investigation in the archives (ihrāă al-hăal ${ }^{19}$ ). The department of land tax for the Sawād issued a report (harağ ${ }^{20}$ ) in which it was mentioned that the assessment went back to an approved account (̌̆amāa $\left.a^{21}\right)$ of the revenue officer for the previous year. In the report (tahri $\left.\check{g}^{22}\right)$ it was found that the division of the taxes of the village, ${ }^{23}$ about which he had complained, had also been carried out on the basis of the higher assessment (istān). ${ }^{24}$

15. Qudāma b. Ğa far, Kitāb al-harāăğ, p. 63-64. My translation of this passage is based in part on HECK 2002, p. 87, with some additions and modifications in wording.

16. On Ibn al-Furāt's three vizierates, see SOURDEL 1959-1960, p. 387-394, 406-414, 424-434.

17. A qațí $a$ is an administrative grant made to estate-holders from whom the lower 'ušr (tithe) tax rather than the full harāă was due. Al-Hुwārazmī, Mafātih al-'ulūm, p. 72.

18. Al-Ṣābi', Tuhfat al-umarā' fì ta'rīh al-wuzarā', p. 163. Al-Hwwārazmī defines istān as muqāsama (a fixed share of the harvest, measured after the crops had ripened). Al-Hwārazmī, Mafātih al-'ulūm, p. 72. However, here, as in many other sources, the istān method of taxation is contrasted with the qațí $a$, a land grant paying the 'ušr. As Løkkegaard suggests, the meaning of mu'ämalat al-istān might here better be translated as a method of tax assessment levied upon the rural population of estates and state domains, being, at least, a higher percentage than the tithe and probably the full ḩarāă. LøKKEGAARD 1950, p. 87.

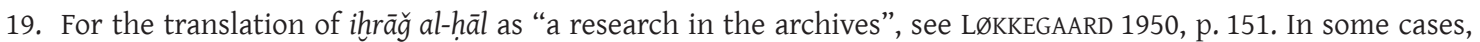
such research in the records was carried out by an official dispatched to the district in question in order to investigate the local situation. See al-Șābi', Tuhfat al-umarä' fì ta'rīh al-wuzarā', p. 165.

20. Harağ is an administrative term for a report or opinion drawn up by the officials of the competent department on the basis of a local and/or archival investigation on the matter. See al-Șābi', Tuhfat al-umarä' fì ta'rīh al-wuzarä', p. 66, p. 163, and p. 166, and LøKKEGAARD 1950, p. 151.

21. For a translation of the term ğamā'a as "an account of an 'ämil that has been approved after an audit", see al-Hwwārazmī, Mafātih al-'ulūm, p. 70, and LøKKEGAARD 1950, p. 183.

22. The term tahrǐg is probably derived from harağ, report or account; see above.

23. The division of the taxes under the muqāsama system took place on the threshing floor (baydar) after the crops had ripened and been collected. LøKKEGAARD 1950, p. 181. See also CAMPOPIANO 2011.

24. Al-Șābi', Tuḥfat al-umarā' fì ta'rīh al-wuzarā', p. 163-164. 
In other words, according to the investigation by the land-tax department, the petitioner was wrong, as he had received the same assessment as in the previous year. However, Hilāl al-Șābi' continues, the petitioner persisted in his complaint and maintained that the harvest of the previous year had been divided on the basis of the lower assessment. He continued to show up on the days the vizier heard complaints. He even buttonholed the vizier in the street and asked him repeatedly to review his case. The vizier finally decided to look into the matter himself. He told the petitioner that he needed a document (huğğa) as evidence against the revenue officer. Unfortunately, the petitioner had no written proof. The vizier then studied the approved account of the revenue officer himself and discovered that the revenue officer had cheated by erasing numbers in the account. After discovering this corruption the vizier assured the petitioner that his privilege was indeed valid.

\section{A petition to an amīr}

The third source, a papyrus from the John Rylands University Library of Manchester, is dated to the third/ninth or fourth/tenth century. ${ }^{25}$ It is a petition by a Christian monk in Asyūt, in Upper Egypt, who wrote on behalf of his fellow monks to an anonymous amir (governor or one of his representatives in the districts), ${ }^{26}$ complaining about local government officials and their local chief who had treated them harshly. He suggests that religious discrimination might be the reason for this behavior. He ends his letter begging the amir to rectify the injustice that he and his fellow monks have suffered:

14. the [amir - God prolong] his life! - because of what we have heard of his just treatment and the justice which he has dispensed to his subjects, both near

15. [and far], (seeking refuge) in God and in the justice of the amir - God prolong his life and make his might last! - for him to be kindly disposed towards us

16. [in h]is plentiful kindness and justice. We [se]ek refuge in God and in the justice of the amir in the matter of these supporters/officials ( $\left.a^{i} w \bar{a} n\right) 27$

17. and their leader, the head of the district. He has destroyed us and declared our property ownerless. He has attacked us unjustly and outrageously

18. ... the tyrant. We pay him a quarter of a dinar per month in... dinars...

19. Injustice... enmity and compulsion. We have no cultivable land nor livestock. Why do they show us hostility? Is it (because of) our religion

20. or (that) we are defenseless and wretched?28

25. P.Ryl.Arab II ADD. no. 354 .

26. It is unclear to which administrator on what level the term amir in this context refers. He could be either the provincial governor or one of his representatives at the district level.

27. Mentioned earlier in the document as a'wān min al-sultān.

28. The translation is by the editors of the text, Rex Smith and Moshalleh al-Moraekhi, with some modifications in wording and transliteration, p. 187-188. 


\section{Mazōlim practices and procedures}

What do these three diverse fragments tell us about the functioning of mazālim (petition and response procedures) in the late third/ninth and early fourth/tenth century Abbasid empire? We must bear in mind that the first two sources describe the submission of petitions and complaints in the center of the empire, Baghdad, while the third source, the papyrus, records a petition in the province of Egypt. The third source is, however, essential for our understanding of petitioning in everyday practice. Most importantly, actual petitions such as these demonstrate that complaints were indeed submitted to superior state officials and that petitioning was more than a description of an ideal or a norm for just rule. The fragments will be analyzed by comparing them with one another and with the detailed theoretical exposition on mazālim procedures by al-Māwardī.

Let us look first into the terminology used for petitioning in these three fragments. The three sources use (partly) different terminology. Qudāma b. Ğafar, in the first fragment, writes about a dīwān al-mazālim, an administrative department or field of expertise dealing with petitions. The person responsible for this dīwān is called the șāhib dīwān al-mazālim; a petitioner is a mutazallim or räfi; a petition is a qișsa; and the response or decision on a petition is a tawqî̀. In the second fragment Hilāl al-șābi' also uses various forms of the root $z-l-m$ to indicate petitioning or complaining. In this fragment he makes one reference to mazālim as an actual institution, when he describes the vizier Ibn al-Furāt chairing the mazālim on specific days of the week. In this fragment, a petition is a ruq'a and the decision on a petition again a tawqî. The papyrus containing the petition from the monk in Asyūt does not mention mazālim as an institution but uses various forms of the root $z-l-m$ to indicate acts of oppression and injustice.

The deciding authorities who are approached by the petitioners in these three fragments are, respectively, the caliph, the vizier, and an amir. These persons are in line with what al-Māwardī prescribes in his al-Aḥkām al-sulțāniyya on deciding authorities, although it is unclear to whom the term amir refers: "Only one eligible for succession to the throne, a delegated ministry, or a governorship (imāra) may be invested with the full powers of a magistrate for the redress of wrongs." ${ }^{29}$ While in the early days of the Abbasid caliphate the caliph was said to have supervised mazālim in person, ${ }^{30}$ in the late third/ ninth and early fourth/tenth centuries the caliph appeared only sporadically, if at all, in mazālim meetings. Likewise, the vizier's responsibility for mazālim did not mean that he always supervised the sessions in person. He often acted through a representative, for example, one of his personal secretaries. ${ }^{31}$ Moreover, he was assisted by a team of scribes,

29. Al-Māwardī, al-Aḥkām al-sulțaniyya, p. 97. The translation is by WAHBA 1996, p. 87, with some modifications in wording.

30. See, for example, SOURDEL 1959-60, p. 641-642: al-Mahdī and al-Hādī took care of the petitions themselves, while Hārūn al-Rašîd was the first to leave them to his vizier.

31. Ibn Muqla, for example, represented the vizier Ibn al-Furāt during the latter's first vizierate. Al-Ṣābi', Tuhfat al-umarā' fì ta'rīh al-wuzarā', p. 107-108. 
who seem to have prepared the petitions, conducted the necessary research, take care of the routine work, and presented more complicated matters to the vizier, the caliph, or one of their representatives..$^{32}$ The vast majority of the petitions were most probably dealt with routinely by the administrative staff. In our second fragment the petition of the estate holder is dealt with by officials from the relevant diw $\bar{a} n$ who write a report to inform the vizier. The vizier himself steps in only after repeated complaints from the petitioner.

Al-Māwardī says also: "A person of lesser standing and importance [than the caliph, vizier, or amir ] may, however, be restricted to the enforcement ofjudgments of the settlement of issues that are beyond the capacity or mandate of judges, provided he is fearless in the pursuit of truth and utterly incorruptible." ${ }^{33}$ It is again unclear to whom al-Māwardī refers with the term amir. It could be the provincial governor or also his subordinates in a certain district of the province. However, he evidently distinguishes the amir from administrators of lesser standing. Therefore his statement - that persons of lesser standing can deal only with cases that are beyond the capacity of the qādi - does not seem to corroborate what Lucian Reinfandt demonstrates in his article in this volume on the downgrading of judicial competences and the role of the subordinates of the pagarchs in addressing complaints. ${ }^{34}$ As for the narrative sources, some of the cases do indeed discuss lower-grade officials or even palace servants dealing with complaints. Most famous is the story of the harem stewardess Thumal, who acted as the caliph's deputy in mazālim matters in al-Rușāfa, one of the districts of Baghdad. ${ }^{35}$ Most of the narrative sources contain, however, very limited information on lower officials dealing with complaints and generally discuss either the caliph or the vizier redressing wrongs. ${ }^{36}$

Information on the identity of the petitioners in these three fragments is limited: the first fragment does not mention particular petitioners, the second mentions an anonymous estate holder from the Sawād, and the third an anonymous monk from Upper Egypt. Who filed petitions? Was any subject from any background allowed to file a complaint? Did some groups rely more than others on this right? Did non-Muslims, for example, rely more often on mazālim jurisdiction than did Muslims? These questions are difficult to answer from the material we have so far, but there are a few things we can say. First, the aggrieved party could be a group such as the monks from Asyūt in our third fragment, or, as in other examples from The Book of Viziers by Hilāl al-Ṣābi', estate-holders from Mecca complaining about the water supply in their area, and inhabitants from a district west of Baghdad

32. See, Qudāma b. Ğafar on this in the fragment mentioned above and also al-șābi', Tuhfat al-umarä' fì ta'rīh al-wuzarä', p. 52.

33. Al-Māwardī, al-Ahkām al-sultaniyya, p. 97. The translation is by WAHBA 1996, p. 87, with some modifications in wording.

34. See REINFANDT's contribution to the present volume.

35. She had been chosen for this position by the caliph's mother. 'Arïb, Șilat ta'rỉh al-Ṭabarī, p. 67.

36. Interesting exceptions are among the references in narrative sources to judges responsible for mazālim in provincial towns. See TILLIER 2009. 
complaining about the way in which their governor had maltreated them. ${ }^{37}$ Individuals, too, such as the estate holder from the Sawād in our second fragment, filed petitions. What about the background, the social status, of the petitioners? Many cases deal with estateholders, people who obviously belonged to the local elites. The documentary sources, dealing with petitioning on a provincial and local level indicate, however, that people of lower social status also submitted petitions to the higher authorities. The narrative sources corroborate this view, at least in theory, as they suggest that any aggrieved inhabitant of the state could file a complaint and that it was the ruler's responsibility to restore justice for all. In one of the reports from The Book of Viziers by Hilāl al-Șābi', the vizier Ibn al-Furāt, overwhelmed with too much work and unable to deal with all the petitioners, is said to have exclaimed: "But we cannot send away from our door the many people who walked here from distant regions and remote districts to explain their complaints." 38

Moreover, according to al-Māwardī, an actual petitioner was not always required to begin a mazālim case. He says that in three types of cases - maltreatment by officials, injustice in fiscal matters, and control of department clerks - the state could initiate a mazālim procedure in the absence of an actual complainant. Qudāma b. Ğa'far does not talk about these cases, but Hilāl al-Ṣābi' describes one other case in which the vizier is said to have taken the initiative. 'Alī b. 'İsā, vizier to caliph al-Muqtadir, is said to have begun investigations into the legality of additional taxes (takmila) paid by the farmers of Fārs, while their colleagues cultivating fruit trees paid no taxes at all. This interesting case was finally settled in a series of mazālim sessions in which the representatives of the two parties sent delegations to the capital to argue their side of the story. ${ }^{39}$

Finally, the three fragments provide us with information on the administrative rules and procedures governing petitioning. All three fragments describe the procedures as beginning with the submission of a written petition that could, as in the case described by Hilāl al-Ṣābi' (fragment 2) and in the description by Qudāma b. Ğa far (fragment 1), be explained orally and expanded in an audience setting. In most of the other cases studied, written petitions were filed, sometimes in the absence of the petitioners. ${ }^{40}$ Some reports show that it was possible to submit oral complaints that were written down by the scribes working for the maz̄ālim. ${ }^{41}$

37. Al-Ṣābi', Tuhfat al-umarā' fì ta'rīh al-wuzarā', p. 346.

38. Al-Șābi', Tuhfat al-umarā' fì ta'rīh al-wuzarā', p. 107.

39. Al-Șābi', Tuhfat al-umarā' fì ta'rīh al-wuzarā', p. 339-344. The other famous vizier of al-Muqtadir's reign, Ibn al-Furāt, was praised for his initiatives in combating official abuses and might have initiated mazālim sessions in that context. See, for example, al-Șābi', Tuhfat al-umarā' fì ta'rīh al-wuzarā', p. 66-67, 113, 283-285, 336-337, 337-339, 345, and 346. Moreover, the numerous actions for the discharge of officials - which have been omitted from this research but which might be classified as mazālim under the definition of al-Māwardī- were also initiated by state officials.

40. See, for example, al-Ṣābi', Tuhfat al-umarā' fì ta'rīh al-wuzarā', p. 337-339.

41. See, for example, al-Ṣābi', Tuhfat al-umarā' fì ta'rīh al-wuzarā', p. 52. See also NiELSEN 1985, p. 10, for similar Fātimid practices. 
Both Qudāma b. Ğa far and Hilāl al-Șābi' illustrate that the caliph or his representatives set specific days on which they dealt with petitions. Both examples show us also the sorts of steps that could be taken after the submission of a petition. The narrative from Hilāl al-Șābi' also has a normative character, providing an example of good governance with a happy end, although it also demonstrates much more clearly than the fragmented information from the documentary sources does, the actual procedures regulating petitioning. One of the most interesting features of the mazālim judicial system, as described by al-Māwardī, is that its procedures are much more flexible than those of the qā example, the possibility of postponing sentencing when further investigation is necessary, the freedom to take the initiative to conduct inquiries, the greater liberty in the admission of (documentary) evidence, and the greater power to summon witnesses. The greater liberty regarding documentary evidence especially is discussed in detail by al-Māwardī. ${ }^{42}$ In line with this theoretical description, we see in Hilāl al-Șābi"s example the staff of a dīwān al-Sawād investigating the matter and the vizier then initiating an investigation of the matter himself. This case shows further the acceptance of written evidence in place of (or in addition to) oral testimony. The extensive use of bureaucratic writing in general is striking in the report by Hilāl al-Șābi', and Qudāma b. Ğa'far's fragment corroborates this. In the case described by al-Ṣābi' no fewer than six types of specialized documents were used, and Qudāma b. Ğafar talks about the extensive registration of both the petitions and their decisions in the archives of the dīwān al-mazālim.

We may conclude from these three examples from different types of sources that the mazālim as a separate and recognizable judicial institution, with a clearly defined jurisdiction, does not seem to have developed fully during this period. In the Abbasid era, however, both provincial and central authorities were supposed to redress wrongs in a general sense and were indeed handling petitions from their subjects. This was not just a concept of good governance - an ideal - but was an actual practice. Some rules and regulations guiding the petitioning processes - although perhaps not fully formed - can still be discerned and can best be understood by combining information from documentary and narrative sources.

\section{Bibliography}

\section{Sources}

'Arīb b. Sa'd al-Qurțubī, Șilat ta'rīh al-Ṭabarī, ed. Muhammad Abū al-Faḍl IBRĀHĪM, [Cairo,] Dār al-Ma'ārif (Abū Ǧa far al-Ṭabarī. Ta'rīh al-Ṭabarī 11; Dַahāìir al-'Arab 30), 1977.

Buhārī (al-), Șāhịḥ, 4 vols. ed. M. Ludolf KREHL and Theodoor Willem JuYNBOLL, Leiden, Brill, 1862-1908. Huwārazmī (al-), Mafātīh al-'ulūm, ed. Ǧawdat FAHR AL-Dīn, Beirut, Dār al-Manāhil, 1991. 
Ibn Wahb, al-Burhān fì wuğūh al-bayān, ed. 'Abd al-Razzāq al-MAṬLŪB and Khadīğa ḤADĪTHĪ, Baghdad, Ǧāmi'at Baghdad, 1967.

Māwardī (al-), al-Ahkām al-sulțāniyya, Beirut, Dār al-Kutub al-'Ilmiyya, [ca. 1980].

Nizām al-Mulk, The Book of Government or Rules for Kings. The Siyar al-muluk or Siyasat-nama of Nizam al-Mulk, transl. Hubert DARKE, London and New York, Routledge, 2002.

P.Cair.Arab. I = Arabic Papyri in the Egyptian Library, ed. Adolf GroHMAnN, Cairo, Egyptian Library Press, 1934.

P.Khalili I = Arabic Papyri: Selected Material from the Khalili Collection, ed. Geoffrey KHAN, Oxford, The Nour Foundation in association with Azimuth Editions and Oxford University Press, 1992.

P.Ryl.Arab II = The Arabic Papyri of the John Rylands University Library of Manchester, ed. G. Rex SMITH and Moshalleh AL-MORAEKHI, Machester, Manchester University Press (Bulletin of the John Rylands University Library of Manchester 78-2), 1996.

Qudāma b. Ǧa far, Kitāb al-harāă wa-șinā'at al-kitābā, ed. Muhammad Ḥusayn AL-ZUBAYDĪ, Baghdad, Dār al-Rašĩd li-l-Našr, 1981.

Șābi' (al-), Hilāl, Tuhfat al-umarā' fì ta'rīh al-wuzarā': The Historical Remains of Hilāl al-Șabì'. First Part of his Kitab al-Wuzara (Gotha Ms.1756) and Fragment of his History 389-393 A.H. (B.M.Ms, add.19360), ed. H. F. AMEDROZ, Beirut, s.n., 1904.

\section{Studies}

AMEDROZ, H. F., 1911, “The Maz̄ālim Jurisdiction in the Aḥkam Sulțaniyya of Māwardī”, Journal of the Royal Asiatic Society 43/3, p. 635-674. DOI: 10.1017/S0035869X00041873

BERKEL, Maaike van, 2011, "Embezzlement and Reimbursement. Disciplining Officials in 'Abbasid Baghdad (8th-10th centuries A.D.)", The International Journal of Public Administration 34/11, p. 712-719.

DOI: $10.1080 / 01900692.2011 .598288$

CAMPOPIANO, Michele, 2011, "Land Tax 'alāl-Misāha and Muqāsama: Legal Theory and the Balance of Social Forces in Early Medieval Iraq (6th-8th Centuries C.E.)", Journal of the Economic and Social History of the Orient 54/2, p. 239-269.

HECK, Paul, 2002, The Construction of Knowledge in Islamic Civilization. Qudāma b. Ja far and his Kitāb al-Kharāj wa-Șināàt al-Kitāba, Leiden, Brill.

KHAN, Geoffrey, 1990a, "The Historical Development of the Structure of Medieval Arabic Petitions", Bulletin of the School of Oriental and African Studies 53/1, p. 8-30.

DOI: http://dx.doi.org/10.1017/S0041977X00021224

KHAN, Geoffrey, 1990b, "A Petition to the Fatimid Caliph al-Amir", Journal of the Royal Asiatic Society 122/1, p. 44-54. DOI: http://dx.doi.org/10.1017/S0035869X00107841

LøKKEGAARD, Frede, 1950, Islamic Taxation in the Classic Period, with Special Reference to Circumstances in Iraq, Copenhagen, Branner \& Korch, 1950 (Reprint, Middle East collection).

NIELSEN, Jørgen S., 1985, Secular Justice in an Islamic State: Mazālim under Bahrī Mamlūks 662/1264-789/1387, Istanbul, Nederlands Historisch-Archaeologisch Instituut.

RiCHARDS, D.S., 1973, “A Fāțimid Petition and Small Decree from Sinai”, Israel Oriental Studies 3, p. 140-158.

RICHARDS, D.S., 1977, "A Mamlūk Petition and a Report from the 'Dīwān al-Jaysh'”, Bulletin of the School of Oriental and African Studies 40/1, p. 1-14. DOI: http://dx.doi.org/10.1017/S0041977X00040362 
RICHARDS, D.S., 1992, "A Petition for an Iqțāe Addressed to Saladin or al-'Ādil", Bulletin of the School of Oriental and African Studies 55/1, p. 100-105. DOI: http://dx.doi.org/10.1017/S0041977X00002676

RusTow, Marina, 2010, "A Petition to a Woman at the Fatimid Court (413-414 A.H./1022-23 C.E.)", Bulletin of the School of Oriental and African Studies 73/1, p. 1-27.

DOI: http://dx.doi.org/10.1017/S0041977X09990322

SOURDEL, Dominique, 1959-1960, Le vizirat 'abbāside de 749 à 936, 2 vols., Damascus, Institut Français de Damas.

STERN, S.M., 1962, “Three Petitions of the Fatimid Period", Oriens 15, p. 172-209.

[Online] http://www.jstor.org/stable/1579846

STERN, S.M., 1964, "Petitions from the Ayyubid Period", Bulletin of the School of Oriental and African Studies 27/1, p. 1-32. DOI: http://dx.doi.org/10.1017/S0041977X00100278

STERN, S.M., 1966, "Petitions from the Mamluk Period", Bulletin of the School of Oriental and African Studies 29/2, p. 233-276. [Online] http://www.jstor.org/stable/611178

TILLIER, Mathieu, 2009, "Qādị̄s and the Political Use of the Mazālim Jurisdiction under the "Abbāsids", in Christian LANGE and Maribel FIERRO (eds.), Public Violence in Islamic Societies, Edinburgh, Edinburgh University Press, p. 42-66. DOI: http://dx.doi.org/10.3366/edinburgh/9780748637317.003.0003

TYAN, Émile, 1960 2nd edition, Histoire de l'organisation judiciaire en pays d'Islam, Leiden, Brill.

VIKøR, Knut, 2005, Between God and the Sultan. A History of Islamic Law, Oxford, Oxford University Press. 